\title{
Human prion disease
}

INSERM

\section{Source}

INSERM. (1999). Orphanet: an online rare disease and orphan drug data base. Human prion disease. ORPHA:56970

Prion diseases are a group of rare transmissible disorders characterized by progressive debilitating neurological manifestations due to spongiform changes with an invariably fatal course. The disorders all involve accumulation of an abnormal prion protein in the central nervous system with no specific immunological response. Sporadic CreutzfeldtJakob disease (CJD; see this term) is the most frequent form accounting for about $85 \%$ of prion disease cases. The other forms of prion disease are genetic (5-15\%) and include inherited CJD, fatal familial insomnia (FFI), and Familial Alzheimer-like prion disease (see these terms). Acquired forms ( $<5 \%$ ) include iatrogenic CJD and variant CJD (VCDJ). 